\title{
Safe re-use practices in wastewater-irrigated urban vegetable farming in Ghana
}

\author{
Bernard Keraita $^{\mathrm{a}, \mathrm{e} *}$, Robert C. Abaidoo ${ }^{\mathrm{b}}$, Ines Beernaerts ${ }^{\mathrm{c}}$, Sasha Koo-Oshima ${ }^{\mathrm{d}}$, Philip Amoah ${ }^{\mathrm{a}}$, \\ Pay Drechsel ${ }^{a}$, and Flemming Konradsen ${ }^{\mathrm{e}}$
}

Submitted 14 July 2011 / Revised 1 December 2011, 22 December 2011, and 10 February 2012 /

Accepted 8 March 2012 / Published online 7 August 2012

Citation: Keraita, B., Abaidoo, R. C., Beernaerts, I., Koo-Oshima, S., Amoah, P., Drechsel, P., \& Konradsen, F. (2012).

Safe re-use practices in wastewater-irrigated urban vegetable farming in Ghana. Journal of Agriculture, Food Systems, and

Community Development, 2(4), 147-158. http://dx.doi.org/10.5304/jafscd.2012.024.004

Copyright (C) 2012 by New Leaf Associates, Inc.

\begin{abstract}
Irrigation using untreated wastewater poses health risks to farmers and consumers of crop products, especially vegetables. With hardly any wastewater treatment in Ghana, a multiple-barrier approach was adopted and safe re-use practices were developed through action research involving a
\end{abstract}

\footnotetext{
a International Water Management Institute, Africa Office, Accra, Ghana.

b College of Agricultural and Natural Resources, Kwame Nkrumah University of Science and Technology, Kumasi, Ghana.

c United Nations Food and Agriculture Organization (FAO), Sub-regional Office for West Africa, Accra, Ghana.

d FAO, Wastewater Guidelines Committee Member, Headquarters, Rome, Italy.

e Department of International Health, University of Copenhagen, Denmark.

* Corresponding author: B. Keraita; International Water Management Institute, Kumasi Office; KNUST; Kumasi, Ghana; +233 322060206; b.keraita@sund.ku.dk
}

number of stakeholders at different levels along the food chain. This paper presents an overview of safe re-use practices including farm-based water treatment methods, water application techniques, post-harvest handling practices, and washing methods. The overview is based on a comprehensive analysis of the literature and our own specific studies, which used data from a broad range of research methods and approaches. Identifying, testing, and assessment of safe practices were done with the active participation of key actors using observations, extensive microbiological laboratory assessments, and field-based measurements. The results of our work and the work of others show that the practices developed had a great potential to reduce health risks, especially when used to complement each other at different levels of the food chain. Future challenges are the development of a comprehensive framework that best combines tested risk-reduction strategies for wide application by national stakeholders as well as their potential implementation into legally enforceable national standards. 


\section{Keywords}

Ghana, health risks, irrigated urban agriculture, safe re-use practices, wastewater

\section{Introduction}

There is increasing food demand in many cities in resource-poor countries due to the rise in urban populations. While commodities like cereals can be transported from rural areas to urban areas, perishable crops like vegetables lose their market value during transportation, as refrigeration facilities are scarce in Africa. Most vegetables are therefore grown in and around cities to maintain their freshness and nutritional value. In many West African cities, more than 90 percent of vegetables consumed are grown within cities (Drechsel, Graefe, Sonou, \& Cofie, 2006). In Accra, the capital city of Ghana, about one thousand farmers are involved in this practice, and daily, about 200,000 Accra residents consume the vegetables that these farmers produce (Obuobie, Keraita, Danso, Amoah, Cofie, Raschid-Sally, \& Drechsel, 2006). Though largely informal, this practice is now an important means of attaining urban food security and sustaining the livelihood of many urban dwellers in resource-poor countries.

Vegetables have high water requirements and need to be irrigated on a daily basis; therefore, vegetable farming requires constant availability of water. Unfortunately, in Ghana as in many other developing countries, urban water bodies are heavily contaminated with untreated wastewater (Amoah, Drechsel, \& Abaidoo, 2005). This is because many cities in resource-poor countries lack the capacity to effectively collect and treat wastewater. In Ghana, most wastewater that farmers use is from domestic sources, as industrial development is limited and localized, so most contamination is of a microbiological and not chemical nature (more of pathogens than heavy metals) (Drechsel et al., 2006). A recent survey suggests that in and around three out of four cities in the developing world, wastewater without any significant treatment is used for irrigation purposes (Raschid-Sally \& Jayakody, 2008). In many cases, farmers have no other option for irrigation beyond using these water sources of marginal quality. In any case, these sources are affordable and reliable, thus enabling cultivation of vegetables throughout the year.

However, the use of untreated wastewater from domestic sources in irrigation is known to transmit excreta-related diseases as it has high levels of pathogenic microorganisms such as bacteria, viruses, parasitic worms, and protozoa (Blumenthal, Peasey, Ruiz-Palacios, \& Mara, 2000). The groups most affected by this issue are consumers of wastewater-irrigated produce and farmers who are in contact with wastewater. This practice has therefore raised public health concerns, and for this reason policy-makers do not support peri-urban and urban agriculture. Nevertheless, with increasing global water scarcity, urbanization, and related food demands in growing cities, irrigating crops using the available marginal-quality water is expected to continue. Appropriate strategies for reducing health risks are therefore an absolute and urgent necessity to make the practice beneficial and more sustainable. In Ghana, the national authorities are well aware of the challenge offered by wastewater use in agriculture, and Ghana's National Irrigation Policy encourages research on safe irrigation practices for irrigated urban and peri-urban agriculture using wastewater (MOFA-GIDA, 2011).

Over the years, conventional wastewater treatment has been widely acknowledged as the ultimate measure for reducing health risks in irrigated agriculture. However, wastewater treatment levels in many developing countries are low, with subSaharan Africa treating less than 1 percent of its wastewater (World Health Organization [WHO] \& UNICEF, 2000). Recognizing this limitation, there is increasing advocacy for other measures that could be more appropriate for risk reduction in developing countries. For example, the 2006 WHO wastewater guidelines encourage the use of a multiple-barrier approach by combining health protection measures to reduce health risks in order to meet required health-based targets (WHO, 2006).

Since the level of conventional wastewater treatment is low in Ghana, as it is in many developing countries, the focus has been on prioritizing affordable and easily adoptable safe re-use practices. Although the long-term goal of integrated 
wastewater management will always be to move from the unregulated use of untreated wastewater to the regulated use of treated wastewater, the medium-term strategy should be to apply the most effective intermediate options for risk management along the "farm to fork" (production to consumption) pathway. Related costs are likely to be low in comparison with constructing, operating and maintaining conventional wastewater treatment plants, not to mention in comparison to the costs of recovering from any wastewater-related epidemics. In addition, water- and food-related health risks require a comprehensive approach as wastewater is not the only source of contamination. Guided by this philosophy, initiatives in Ghana were undertaken to test and monitor the application of a set of intermediate options for risk reduction. A number of institutions supported by FAO and WHO have been working with farmers and other stakeholders to develop and implement on-farm and off-farm safe re-use practices for wastewater-irrigated vegetable farming in urban environments. Below we present an overview of safe re-use practices and key lessons learned, based on studies we and others did to test risk-reduction measures in wastewater agricultural production and marketing systems in Ghana.

\section{Methodology}

\section{Study Area}

The studies were conducted in Accra and Kumasi, the two largest cities in Ghana. In these cities, vegetables are grown all year round and sold in local markets. In Kumasi, about 99 acres (40 ha) of land is cultivated by about 600 farmers, while in Accra, 800 to 1000 farmers engage on inner-city cultivation, varying between 116 acres (47 ha) during the wet season and 400 acres (162 ha) during the dry season (Obuobie et al., 2006). The main crops grown in these sites are lettuce, cabbage, and spring onions. Farmers use dugouts (small shallow ponds), streams, and drains, usually polluted with untreated wastewater, as sources of irrigation water. Levels of fecal coliforms in the irrigation water usually vary between 5 and $9 \log$ units per $100 \mathrm{ml}$ and helminth eggs between 1 and 6 per liter (Akple, 2009; Amoah et al., 2005).

\section{Data Collection}

A number of approaches and methods were used to collect the data presented and discussed in this paper. A participatory action research approach was used with key stakeholders (farmers, vegetable sellers) who were actively engaged in identifying and testing low-cost and safe re-use and riskreduction practices. The Visualization in Participatory Programs (VIPP) approach (Rifkin \& Pridmore, 2001), was used to identify feasible and safe re-use practices. This was followed by testing of the identified practices and quantifying their impacts on risk reduction and productivity. For farm-based trials, the on-farm research process (see Dorward, Galpin, \& Shepherd, 2003), which is a cyclical needs assessment, experimentation, and dissemination process, was adapted where farmers tested the feasible and innovative practices on their own farming plots. Observations and farmer interviews and feedback sessions were conducted throughout the study. Assessment parameters used were yields (to measure productivity), and counts of thermo-tolerant coliforms and helminth eggs (indicators for risk reduction). For post-harvest measures, testing was done in markets and under laboratory conditions. Analysis of vegetables was done also for helminth eggs and fecal coliforms. An overview of specific risk reduction measures studies we conducted at different levels is presented in table 1.

\section{Results and Discussion}

\section{Safe Re-use Practices}

Figure 1 presents a summary of the tested safe reuse practices. Testing was done on both farmbased practices (with farmers in the farmers' own plots) and also on post-harvest practices, mostly handling and washing at markets, street kitchens, and households.

\section{Farm-based practices}

\section{On-farm treatment to improve water quality}

Simple on-farm sedimentation ponds: In Ghana, as in many other countries in West Africa, shallow dugout ponds usually less than 3.3 feet (1 $\mathrm{m})$ deep and 6.6 feet $(2 \mathrm{~m})$ wide are widely used in 
Table 1. Overview of Specific Studies for Testing and Assessing Risk Reduction Measures

\begin{tabular}{|c|c|c|c|}
\hline Level & Location and Period & Objective and Measures Tested & Methods \\
\hline Farm level & $\begin{array}{l}\text { Kumasi, Ghana, } \\
\text { 2005-2008 }\end{array}$ & $\begin{array}{l}\text { To the test effectiveness of low-cost } \\
\text { measures on reducing risks at farms } \\
\text { Measures tested: } \\
\text { 1. On-farm sedimentation ponds } \\
\text { (Keraita, Drechsel, \& Konradsen, } \\
\text { 2008a) } \\
\text { 2. Filtration systems (Keraita, } \\
\text { Drechsel, \& Konradsen, 2008b) } \\
\text { 3. Irrigation Methods (Keraita, } \\
\text { Konradsen, Drechsel, \& Abaidoo, } \\
\text { 2007a) } \\
\text { 4. Cessation of irrigation before } \\
\text { harvesting (Keraita, Konradsen, } \\
\text { Drechsel, \& Abaidoo, 2007b) }\end{array}$ & $\begin{array}{l}\text { - On-farm testing and joint assess- } \\
\text { ments with farmers } \\
\text { - Environmental sampling and labora- } \\
\text { tory analysis (water, soil, crop } \\
\text { samples) } \\
\text { - Observations } \\
\text { - Interviews with farmers }\end{array}$ \\
\hline $\begin{array}{l}\text { Post-harvest } \\
\text { level }\end{array}$ & $\begin{array}{l}\text { Kumasi and Accra, } \\
\text { Ghana, 2006-2009 }\end{array}$ & $\begin{array}{l}\text { To the test effectiveness of low-cost } \\
\text { risk reduction at markets and in street } \\
\text { kitchens. } \\
\text { Measures tested: } \\
\text { 1. Cleaning and displaying in markets } \\
\text { (Akple, 2009) } \\
\text { 2. Removal of outer leaves and peel- } \\
\text { ing (Akple, 2009; Keraita et al., } \\
2007 \mathrm{~b}) \\
\text { 3. Washing and disinfection (Amoah } \\
\text { Drechsel, Abaidoo, \& Klutse, 2007) }\end{array}$ & $\begin{array}{l}\text { - Laboratory-based simulation of } \\
\text { washing and peeling } \\
\text { - Environmental sampling and } \\
\text { laboratory analysis (crop and water } \\
\text { samples) } \\
\text { - Interviews with produce sellers and } \\
\text { caterers }\end{array}$ \\
\hline
\end{tabular}

irrigated urban vegetable farming sites. In most cases, they are used as storage reservoirs where surface runoff and wastewater effluents are channelled. Other variations include mobile drums and other reservoirs, which are common in areas where irrigation water sources are distant from farm sites. These are filled manually or by pumping water from streams, and then the water is used for irrigation when needed. In many cases, drums and reservoirs are refilled after several days. While this water is stored and gradually used for irrigation, sedimentation takes place. This provides the opportunity for a simple measure that can improve the quality of irrigation water using similar mechanisms like water storage and treatment reservoirs (WSTRs), although the extent of pathogen removal could be lower. Studies we conducted in Ghana showed that these ponds are very effective in removing helminths (reduced to less than 1 egg per litre) when sedimentation is allowed for 2 to 3 days (Keraita et al., 2008a). We recommended that further reductions could be achieved with better pond designs and training for farmers on how to collect water. In addition, measures that can enhance sedimentation, such as using natural flocculants such as Moringa Oleifera seed extracts in the ponds, seem to be promising in Ghana. Furthermore, use of additional measures that influence pathogen die-off, such as sunlight intensity, temperature, crop type, and more, can help in reducing the pathogen load in irrigation water.

Filtration techniques. There is a wide range of filtration systems, but slow sand filters are probably the most appropriate to treat irrigation water. Sand filters remove pathogenic microorganisms from polluted water by first retaining them in the filtration media before they are eliminated (Stevic, Aa, Ausland \& Hanssen, 2004). The typical pathogen removal range reported by the WHO based on a review on several studies for slow sand filters is $0-3 \log$ units and 1-3 log units 
Figure 1. Overview of Low-Cost Risk-Reduction Measures

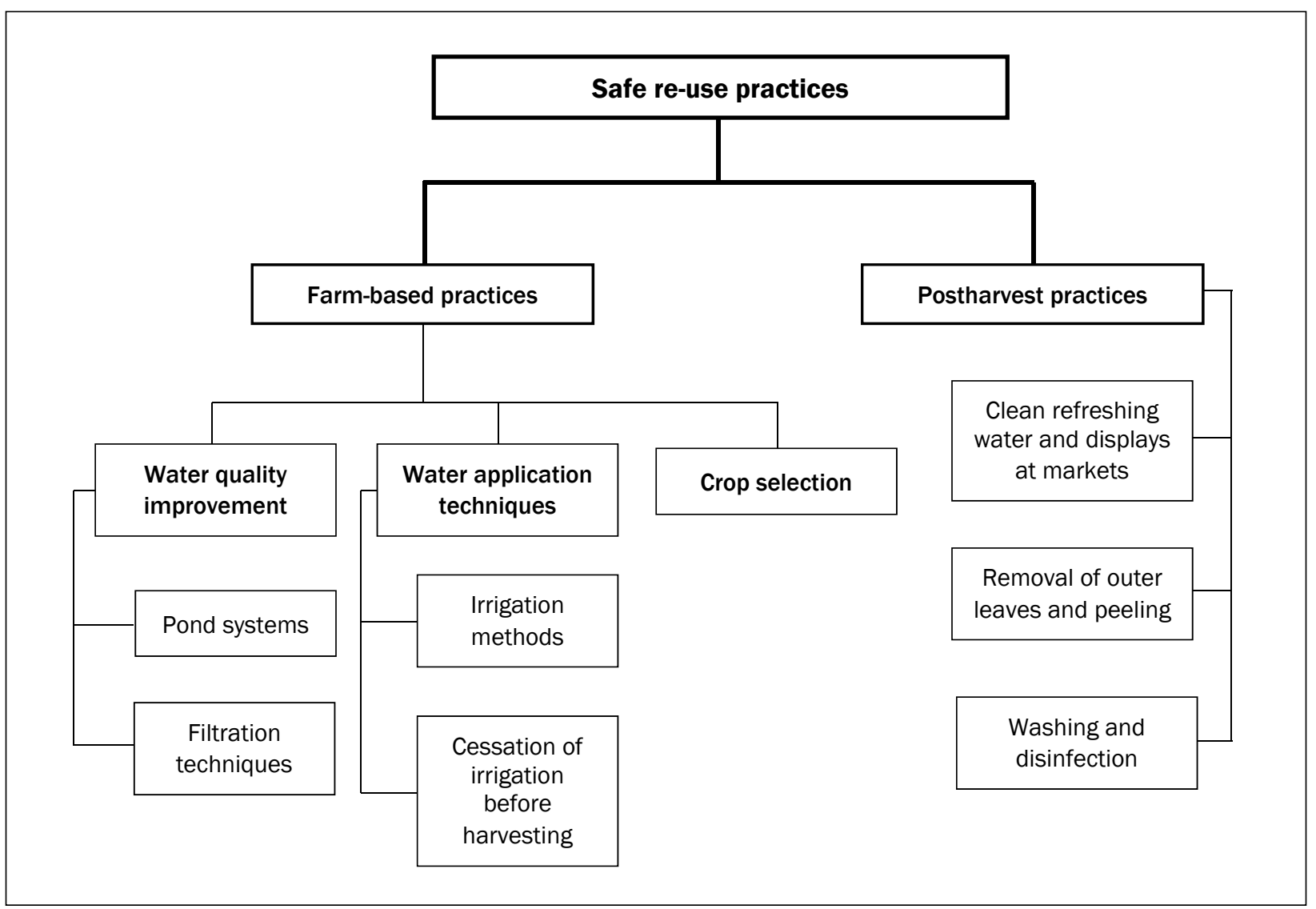

for bacteria and helminths, respectively (WHO, 2006). Our research in Ghana using column slow sand filters achieved between 98.2 percent and 99.8 percent of bacteria removal, equivalent to an average of $2 \log$ units per $100 \mathrm{ml}$ and 71 percent and 96 percent of helminths were removed (Keraita et al., 2008b). This removal was significant but not adequate, as irrigation water had very high levels of indicator organisms.

Farmers in West Africa also use other forms of filtration systems. In Ouagadogou, Burkina Faso, wells are sunk next to wastewater canals to create a hydraulic gradient that enables water to infiltrate the soil layer into the well. In doing so, filtration occurs, leading to a reduction in microorganisms and turbidity. Wastewater can also be allowed to pass through sand filter trenches, sand embarkments, column sand filters, and simple sand bags as farmers channel irrigation water to collection storage ponds. While the reduction of bacteria and virus may be minimal due to their small size, some reduction in protozoa and helminth eggs can be achieved. In Ghana, we found that farmers use different forms of sieves, most frequently folded mosquito nets over watering cans to prevent particles like algae and sand from entering the watering cans. In this method, some pathogens adsorbed the particles are removed. A study of these kinds of simple filter systems shows about 1 $\log$ unit removal for bacteria and 12 percent to 62 percent for helminths when a nylon sieve was used (Keraita et al., 2008b). It is worth exploring further modifications that could be made to increase removal rates, because these are the systems that many farmers find easier to adopt. Clogging is a limitation when using sand filters, but proper choice of filtration media (with the right uniformity coefficient and effective size configurations) can reduce the problem. 
Use of appropriate water application techniques

Irrigation methods. The use of appropriate irrigation methods has also been outlined as one of the health protection measures in wastewaterirrigated agriculture (United Nations Food and Agriculture Organization [FAO], 1992; 2002). Based on health impacts from wastewater, WHO has classified irrigation methods in three categories: flood and furrow, spray and sprinkler, and localized irrigation methods (FAO, 1992; 2002). Flood and furrow irrigation methods apply water on the surface and pose the highest risks to field workers, and more so when protective clothing is not used (Blumenthal et al., 2000). Spray and sprinkler are overhead irrigation methods and have the highest potential to transfer pathogens to crop surfaces, as water is applied on edible parts of most crops and aerosols also result in a wider movement of pathogens (FAO, 1992). Localized techniques such as drip and trickle irrigation offer farm workers the most health protection and also result in minimal pathogen transfer to crop surfaces because water is applied directly to the root (FAO, 1992). However, localized techniques are comparatively the most expensive and are also prone to clogging as polluted water has high turbidity levels. They can reduce contamination on crops by 2 to $4 \log$ units (WHO, 2006). Nevertheless, low-cost drip irrigation techniques like bucket drip kits from Chapin Watermatics (USA) and International Development Enterprises (IDE, India) offer more potential for use in low-income countries, and are now available on the market (Kay, 2001). Our study in Ghana using bucket drip kits show even higher reduction in contamination (up to $6 \log$ units), especially during the dry season (Keraita et al., 2007a). The same study in Ghana also showed great potential for modifying traditional systems, in this case lowering watering cans to reduce splashing of contaminated soils onto crops.

\section{Cessation of irrigation before harvesting.}

Correct water management during application can minimize soil and crop contamination. The timing of irrigation, including frequency, is not only important for pathogen reduction but also for other toxicities (FAO, 1992). In reducing pathogens, one of the most widely documented field water-management measures is cessation of irrigation. Farmers cease irrigation a few days before crops are harvested to allow for pathogens to die off due to exposure to unfavorable weather conditions such as sunlight (Shuval, Adin, Fattal, Rawitz, \& Yekutiel, 1986). As much as 99 percent of detectable viruses have been reported eliminated after two days' exposure to sunlight, supporting regulations that a suitable time interval should be maintained between irrigation and crop handling or grazing time (Feigin, Ravina, \& Shalhevet, 1991). The results from our field trials in Ghana showed an average daily reduction of $0.65 \log$ units of thermo-tolerant coliforms on lettuce (Keraita et al., 2007b). However, this research also showed that cessation has correspondingly high yield losses (1.4 tons/ha of fresh weight), which may make this method harder for farmers to adopt (Keraita et al., 2007b).

\section{Crop selection}

Some crops are more prone to contamination from pathogens, salinity, and toxicity than others. Correct crop selection will lead to decreased human health risks. For instance, crops with their edible parts more exposed to contaminated soils and irrigation water, like low-growing crops and root tubers, will be more prone to pathogen contamination. The WHO guidelines on safe use of wastewater in agriculture recommend restrictions, especially for crops like vegetables that are eaten raw (WHO, 2006). However, a shift in crops is only feasible if the market value of the alternative crops is similar. Crop restrictions can be hard to implement if conditions such as law enforcement, market pressure, and demand for cleaner vegetables are not in place. While there have been successful crop restriction schemes in India, Mexico, Peru and Chile (Blumenthal et al., 2000; Buechler \& Devi, 2003), this has not been possible in other countries, generally those in which wastewater irrigation is informal like in Ghana.

\section{Post-harvest Practices}

\section{Market-based practices}

It is generally recognized that the above farmbased interventions can only reduce, not eliminate, crop contamination at the farm level. Furthermore, 
several studies have shown that further contamination (mainly microbial) can occur during post-harvest handling at markets and consumption points (Amoah et al., 2007; Ensink, Mahamood, \& Dalsgaard, 2007). Therefore, post-harvesting interventions are equally important to ensure more comprehensive food safety.

- Display locations and removal of outer leaves. Vegetables are displayed in various locations while being sold at markets. In the study done in Kumasi, vegetables displayed on bare ground had higher levels of microbiological contamination than those placed on raised tables (Akple, 2009). For example, cabbages displayed on bare ground had average thermo-tolerant levels of $7.75 \mathrm{log}$ units compared to $6.98 \mathrm{log}$ units when they were displayed on raised tables (Akple). Likewise, removal of outer leaves in the market also showed some log reduction. For cabbage, removal of outer leaves reduced thermotolerant coliforms by an average of $1.1 \mathrm{log}$ units per $100 \mathrm{~g}$ wet weight, whereas helminth egg number were reduced by 1.6 egg per $100 \mathrm{~g}$ wet weight (Akple). However, cutting of vegetables before sale in markets tended to increase contamination levels (Akple).

- Using clean refreshing water. The last point of sale can be a street market, a supermarket, or a restaurant selling a salad. Although the standards of these entities in developing countries vary greatly, general food safety considerations are similar, and again are very dependent on the ability to keep the produce under low temperatures and well protected from exposure. Especially in hot climates, it is often technically impossible to conserve unsold leafy vegetables for the next day. Even during the day, water is often used for washing, refreshing, or rehydrating (crisping) fruits and vegetables on display. A pilot study in Kumasi showed that changing this water once during the day can decrease the average fecal coliform counts on lettuce by up to one log unit (Akple, 2009). However in many developing countries, where it is not easy to change water, vegetables are rinsed throughout the day with with water already used to rinse a variety of produce on display, which can lead to cross-contamination
(Amoah et al., 2007). In theory, the use of chlorine tablets could help, but if solutions used for decontamination are not regularly changed, such processing water may become itself a source of contamination. Therefore, clear instructions on dosages and frequencies are necessary. More important is to address the motivation for washing or refreshing vegetables in retail settings. The most obvious motivation is to display "neat" products, which reflects customers' preferences and criteria for purchase, and does not automatically translate into safe products (Henseler, Danso, \& Annang, 2005; Rheinländer, Olsen, Bakang, Takyi, Konradsen, \& Samuelsen, 2008).

\section{Consumer level}

- Improved washing methods. Improved washing methods can achieve about 1-2 log reductions fecal coliforms (depending on the nature of the surface of the leaves), and this can be achieved at markets by washing vigorously in tap water. In Ghana, perception studies show that food vendors are usually confident that their cleaning and treatment is sufficient to eliminate any contaminants. However, assessments done in West African cities show that only few of the methods used in cleaning vegetables achieved some reductions (Amoah et al., 2007). For many methods, adjustments were needed to achieve 2-3 log units' pathogen reductions, Salt $(\mathrm{NaCl})$ is considered the cheapest disinfectant and most likely to be adapted, but it is known to cause deteriorating effects on lettuce at higher concentrations of 23 and $35 \mathrm{ppm}$. A weak $7 \mathrm{ppm}$ $\mathrm{NaCl}$ solution is recommended to achieve some pathogen reduction while preserving freshness of lettuce (Amoah et al., 2007). At A vinegar concentration of $12500 \mathrm{ppm}$ (approximately one part vinegar to five parts water), for example, can reduce pathogen levels significantly and can be achieved with a contact time $\geq 5$ minutes. The efficacy of vinegar and other organic acids as a sanitizer is also confirmed by several others studies. Reduction in counts of Yersinia enterocolitica inoculated onto parsley leaves from $10^{7} \mathrm{CFU} / \mathrm{g}$ to $<1 \mathrm{CFU} / \mathrm{g}$ by washing in a solution containing 40 percent vinegar 
for 15 minutes was achieved by Karapinar \& Gonul (1992). Treatment of ready-to-use salads with $90 \mathrm{ppm}$ peracetic acid has been shown to reduce total counts and fecal coliforms by nearly 100 -fold, which is similar to reductions with 100 ppm chlorine (Masson, 1990). However vinegar is considered to be expensive by most street food vendors and is used mainly by restaurants and middle- and upper-class households (Amoah et al., 2007).

\section{Combining Safe Reuse Practices}

Based on the exposure scenarios of vegetable consumption and relevant epidemiological evidence, it is shown that, in order to achieve $\leq 10^{-6}$ Disability Adjusted Life Years (DALY) per person per year, a total pathogen reduction of $6 \log$ units for consumption of leafy crops (such as lettuce) and $7 \log$ units for consumption of root crops (such as onions) is required (WHO, 2006). In line with the multiple approach concepts, scenarios that combine several methods derived from risk reduction strategies are discussed in this paper. Intraand interlevel combinations can be made. In interlevel combinations, farm-level strategies can be combined with market-level and even consumerlevel strategies for higher cumulative effects. Likewise, a number of strategies can be combined at each level. For example, water treatment at the farm level can be combined with good irrigation techniques to reduce contamination. The sidebar illustrates how practical combinations for strategies tested under the FAO study in Kumasi for cabbage can be achieved.

\section{Enhancing the Adoption of Safe Re-use Practices}

To have the desired impact, key actors in project areas and beyond need to adopt the practices developed in research projects and make them into routine practice. However, adoption of best practices by actors can be slow, dynamic, and complicated due to the multiple factors that influence adoption (Karg \& Drechsel, 2011; Kiptot, Hebinck, Franzel, \& Richards, 2007). Based on our field studies, we describe some specific factors that can enhance adoption of the safe reuse practices that have been developed.

\section{Enabling actors to visualize the invisible.}

One of the greatest challenges in safe wastewater re-use is for farmers to be able to visualize the impacts that safer practices could have on risk reduction. This would influence their risk perceptions and encourage adoption of safer practices. In this study, for instance, farmers relied mainly on physical indicators such as color, odor, and debris on water to ascertain the level of contamination in water and the related risk. In Kano, Nigeria, some of the farmers using untreated industrial effluents from breweries and tanneries used color, smell, and the formation of foam to determine unfavorable and undesirable conditions (Binns, Maconachie, \& Tanko, 2003). Knudsen et al. (2008) similarly illustrated how farmers in peri-urban Hanoi, Vietnam, use locally adapted indicators to characterize wastewater.

Physical indicators, however, do not always correspond to microbiological indicators. For example, shallow wells with clear water and no bad odor — that appeared to be physically clean -

\section{Cumulative Effect of Risk Reduction Strategies for Cabbage in Kumasi}

A farm-level measure - cessation of irrigation before harvesting - reduced thermo-tolerant coliforms by 0.84 log units and 2.4 helminth eggs per $100 \mathrm{~g}$ wet weight cabbage within the acceptable 4 days withholding duration. Good handling practices at the market such as removal of outermost contaminated leaves and displaying cabbages for sale on tables covered with clean sacks led to a further reduction of $0.97 \mathrm{log}$ units of thermo-tolerant coliforms and 0.2 helminth eggs at the market. Washing the cabbages in the kitchen with vinegar further reduced contamination by $2.11 \mathrm{log}$ units and 0.6 for thermo-tolerant coliforms and helminth eggs, respectively. So a total cumulative reduction of 3.92 log units for thermo-tolerant coliforms and 3.2 log units of helminth eggs was achieved. The reduction could be even higher if water treatment methods like sedimentation ponds and better irrigation methods like drip irrigation could be used, as demonstrated in earlier studies done in Kumasi (see Keraita et al., 2007a; 2008a). 
recorded high levels of coliform bacteria similar to water from urban streams that appeared to be physically dirty. Scientists need to work with farmers to validate physical indicators or combinations of physical indicators that could indicate levels of microbiological contamination at the farm level. This routine monitoring will be important as laboratory assessments are not feasible for many of these farmers. On the other hand, farmers want to "see" the effectiveness of the safer practice before changing from their original practices. Participatory field testing to a great extent addresses this challenge as farmers compare new practices with their old practices in their own fields (Doward et al., 2003)

Incentives. For each safe re-use practice, key actors (farmers, vegetable sellers, and food vendors) need to make an investment such as increased labor, capital and operational costs, lower yields, or even the inconvenience resulting from change in behavior. Therefore institutional and individual incentive systems could enhance the adoption of safe practices (Frewer, Howard, \& Shepherd, 1998; Goldstein \& Udry, 1999). Studies show that people are more likely to adopt innovations if they receive more benefits directly than other demographic groups (Frewer et al., 1998). Incentives in Ghana are even more important, as the direct beneficiaries of safe food are not the key actors since the vegetables produced are for sale and are not for household consumption.

One incentive could be to increase the economic return for safer vegetables. This could be achieved by establishing separate marketing channels of safer products (Boateng, Keraita, \& Akple, 2007). Producer groups could also be encouraged to sell their products outside the existing marketing channels to avoid confusion. This could be done by linking farmers directly to large consumers like hotels and demarcating specific selling points in markets and supermarkets. Other incentives could be institutional support from government institutions in the form of provision of extension services in exotic vegetable farming, or loans, awards, or land-tenure security. Karg and Drechsel (2011) identify regulations as an important external factor to institutionalize new food-safety recommendations so as to provide the legal framework for both incentives (such as certificates) and disincentives (such as fees).

Social marketing of safe practices. Social marketing seeks to induce a target audience to voluntarily accept, modify, or abandon behavior for the benefit of individuals, groups, or society as a whole (Grier \& Bryant, 2005; Siegel \& DonerLotenberg, 2007). This could be an important tool to encourage adoption of safe re-use practices in urban vegetable farming in poor settings where economic arguments do not work (Karg \& Drechsel, 2011). Even if health considerations are not valued highly in the target group, socialmarketing studies can help identify valuable related benefits, including indirect business advantages, improved self-esteem, and a feeling of comfort or respect for others. Studies must look for positive, core values the primary target audience can associate with innovative approaches (Siegel \& Doner-Lotenberg, 2007). For example, if using a drip kit for safer irrigation is perceived as being "technologically advanced," then the socialmarketing messages and communication strategies should reinforce this existing positive association (Karg \& Drechsel, 2011).

Innovative knowledge sharing. The various initiatives in Ghana encouraged and facilitated empirical knowledge exchanges among farmers as well as between farmers and scientists. Research findings were synthesized to make farmer-friendly training and extension materials on safe (best) practices. These materials were translated into different local languages and included documentaries (radio and video) as well as illustrated flip charts. In addition, interactive approaches like the Farmer Field School (FFS) approach was used (see Braun \& Duveskog, 2008), where actual training and demonstration of best, safe re-use practices were undertaken. The training modules were prepared by key actors such as farmers and marketers' representatives, extension officers from the Ministry of Food and Agriculture, and communication experts. Modules on safe re-use practices developed in Ghana are now integrated into relevant ministries' formal training curricula, starting with the urban agriculture directorates in Kumasi and Accra. The safe practices developed are disseminated by the ministries' extension 
officials. This will help empower urban farmers to analyze for themselves the conditions in which they work and their own impact on the safety of their products. On a global scale, FAO has guidelines for urban producers (FAO, 2007) and also a program on Food for the Cities (http://www.fao. org/fcit) that addresses training of producers on best practices in producing healthy foods.

Involving authorities. Institutionalizing best practices is important for sustainable adoption (World Bank, 2006). In Ghana, the project involved policy-makers, local authorities, the Ministry of Food and Agriculture, and other relevant agency staff, such as food safety regulators, to support safe re-use initiatives and their institutionalization. While some of them are involved as research partners, the others are kept updated through policy briefs and participation in our project meetings.

Linking with other projects. Wastewater reuse projects should also be linked to other relevant projects or government projects that share this project's goals. This could include government poverty-reduction programs for the urban poor, initiatives for urban food security, nutritional programs that emphasize the consumption of green vegetables, and health programs. For instance, wastewater re-use is just one of the routes by which excreta-related diseases can be transmitted (Gerstl, 2001; Mensah, Yeboah-Manu, OwusuDarko, \& Ablordey, 2002). In poor urban communities, these diseases could be transmitted through poor sanitation or lack of safe drinking water. In such situations, linking wastewater re-use projects to other intervention projects in households in the same studied population would be beneficial. On consumption-related risks, linkages with post-harvest interventions such as handling at markets or washing at homes or eating places will ensure that efforts made in the farms are not futile. For up-scaling to other farming areas with comparable practices, it is important to link with other information systems that provide information on climate, soils, water, and also on the social, economic, and cultural context.

\section{Conclusion}

Farm-based, market-, and consumer-level risk reduction provide more direct solutions to the health challenges in wastewater-irrigated urban and peri-urban agriculture than single strategies.

Though the effectiveness of individual measures in risk reduction may not be sufficient, they can be used in combination to complement each other in order to achieve acceptable risk levels. Combination can be done within and between operation levels, that is, farms, markets and households. While the measures discussed in this paper are the best practices identified for risk reduction from wastewater irrigation in major cities in Ghana, they could still be improved and adapted for use in other locations. At present, one challenge remains the wide application of tested safe re-use practices by national stakeholders and their potential transposition into legally enforceable, monitored, and verified national standards. We also encourage the use of participatory approaches to enhance adoption of these measures by all sectors. Farmers can be encouraged to continue with farm innovations by providing knowledge, incentives, and institutional support, as well as access to higher quality waters and inputs. In addition, it is necessary to raise awareness of the health risks associated with the practice of wastewater irrigation, as well as the overall concepts of hygiene as prescribed by the FAO Codex Alimentarius Committee on Food Hygiene for fresh products and the FAO Good Agriculture Practice (GAP) concepts. This will create demand for safer local products, thereby increasing expectations for farmers to implement these measures through strong governmental support.

\section{Acknowledgement}

Research on the effectiveness of combined lowcost measures to reduce health risks (nontreatment options) was funded by the UN Food and Agricultural Organization (FAO).

\section{References}

Akple, M. S. K. (2009). Assessment of effectiveness of nontreatment interventions in reducing health risks associated with consumption of wastewater-irrigated cabbage (Unpublished master's thesis). Kwame Nkrumah University of Science and Technology, Kumasi, Ghana. 
Amoah, P., Drechsel, P., \& Abaidoo, R. C. (2005). Irrigated urban vegetable production in Ghana: Sources of pathogen contamination and health risk elimination. Irrigation and Drainage, 54(Issue Supplement 1),S49-S61. http://dx.doi.org/10.1002/ird.185

Amoah, P., Drechsel, P., Abaidoo, R. C., \& Klutse A. (2007). Effectiveness of common and improved sanitary methods in West Africa for the reduction of coli bacteria on vegetables. Tropical Medicine and International Health, 12(2), 39-49.

Binns, J. A., Maconachie, R. A., \& Tanko, A. I. (2003). $W$ ater, land and health in urban and peri-urban food production: The case of Kano, Nigeria. Retrieved from www.cityfarmer.org/WaterLandHealthKano.rtf

Blumenthal, U. J., Peasey, A., Ruiz-Palacios, G., \& Mara, D. D. (2000). Guidelines for wastewater reuse in agriculture and aquaculture: Recommended revisions based on new research evidence. WELL study, Task No. 68, Part 1. London: Water and Environmental Health at London and Loughborough (WELL). Retrieved from http://www.bvsde.paho.org/bvsacd/cd25/well.pdf

Boateng, O. K., Keraita, B., \& Akple, M. S. K. (2007). Organic vegetable growers combine for market impact. Appropriate Technology, 34(4), 26-28.

Braun, A., \& Duveskog, D. (2008). Farmer Field School approach - History, global assessment and success stories. Paper commissioned by The International Fund for Agricultural Development (IFAD), Rome, Italy.

Buechler, S., \& Devi, G. (2003). Household food security and wastewater dependent livelihood activities in Andhra Pradesh, India. Unpublished background document prepared for the WHO in preparation for the Guidelines for the safe use of wastewater, excreta and grey water publication.

Dorward, P., Galpin, M., \& Shepherd, D. (2003). Participatory Farm Management methods for assessing the suitability of potential innovations: A case study on green manuring options for tomato producers in Ghana. Agricultural Systems, 75, 97-117. http://dx.doi.org/10.1016/S0308-521X(02) 00034-3

Drechsel, P., Graefe, S., Sonou, M., \& Cofie, O. O. (2006). Informal irrigation in urban West Africa: $A n$ overview. IWMI Research Report 102. IWMI, Colombo.

Ensink, J. H. J., Mahamood, T., \& Dalsgaard, A. (2007). Wastewater irrigated vegetables: Market handling verses irrigation water quality. Tropical Medicine and International Health, 12(2), 2-7. http:/ / dx.doi.org/ 10.1111/j.1365-3156.2007.01935.x

Feigin, A., Ravina, I., \& Shalhevet, J. (1991). Irrigation with treated sewage effluent: Management for environmental protection. Berlin: Springer, and New York: Heidelberg.

Frewer, L. J., Howard, C., \& Shepherd, R. (1998). Understanding public attitudes to technology. Journal of Risk Research, 1(3), 221-235. http://dx.doi.org/10.1080/136698798377141

Gerstl, S. (2001). The economic costs and impact of home gardening in Onagadougou, Burkina Faso (Doctoral dissertation). University of Basel, Switzerland. Retrieved from http://edoc.unibas.ch/diss/DissB_5806

Grier, S., \& Bryant, C. A. (2005). Social marketing in public health. Annual Review of Public Health, 26, 319-339. http://dx.doi.org/10.1146/annurev. publhealth.26.021304.144610

Goldstein, M., \& Udry, C. (1999). Agricultural innovation and resource management in Ghana. Final Report to IFPRI under MP17. Washington, D.C.: International Food Policy Research Institute.

Henseler, M., Danso, G., \& Annang, L. (2005). Lettuce survey (Unpublished project report). Lettuce Survey Component of CP51, CGIAR CPWF Project 51. Ghana: International Water Management Institute.

Karapinar, M., \& Gonul, S. A. (1992). Removal of Yersinia enterocolitica from fresh parsley by washing with acetic acid or vinegar. International Journal of Food Microbiology, 16, 261-264. http://dx.doi.org/10.1016/0168-1605(92)90086-I

Karg, H., \& Drechsel, P. (2011). Motivating behaviour change to reduce pathogenic risk where unsafe water is used for irrigation. Water International, 36(4), 476-490.

http://dx.doi.org/10.1080/02508060.2011.594684

Kay, M. (2001). Smallholder irrigation technology: Prospects for sub-Sahara Africa. Rome: International Programme for Technology and Research in Irrigation and Drainage (IPTRID), FAO. Available at http://www.fao.org/DOCREP/004/Y0969E/y09 69e00.htm

Keraita, B., Konradsen, F., Drechsel, P., \& Abaidoo, R. C. (2007a). Effect of low-cost irrigation methods on microbial contamination of lettuce. Tropical Medicine and International Health, 12(2), 15-22. http://dx.doi. org/10.1111/j.1365-3156.2007.01937.x 
Keraita, B., Konradsen, F., Drechsel, P., \& Abaidoo, R. C. (2007b). Reducing microbial contamination on lettuce by cessation of irrigation before harvesting. Tropical Medicine and International Health, 12(2), 8-14. http://dx.doi.org/10.1111/j.1365-3156.2007. 01936.x

Keraita, B., Drechsel, P., \& Konradsen, F. (2008a). Using on-farm sedimentation ponds to reduce health risks in wastewater irrigated urban vegetable farming in Ghana. Water Science and Technology, 57(4), 519-525. http://dx.doi.org/10.2166/wst.2008.166

Keraita, B., Drechsel, P., \& Konradsen, F. (2008b). Potential of simple filters to improve microbial quality of irrigation water used in urban vegetable farming in Ghana. Journal of Environmental Sciences and Health, Part A, 43(7), 749-755. http://dx.doi.org/10.1080/10934520801959948

Kiptot, E., Hebinck, P., Franzel, S., \& Richards, P. (2007). Adopters, testers or pseudo-adopters? Dynamics of the use of improved tree fallows by farmers in western Kenya. Agricultural Systems, 94, 509-519. http://dx.doi.org/10.1016/j.agsy.2007.01.002 Knudsen, L. G., Phuc, P. D., Hiep, N. T., Samuelsen, H., Jensen, P. K., Dalsgaard, A., Raschid-Sally, L., \& Konradsen, F. (2008). The fear of awful smell: Risk perceptions among farmers in Vietnam using wastewater and human excreta in agriculture. Southeast Asian Journal of Tropical Medicine and Public Health, 39(2), 341-352.

Masson, R. B. (1990). Recherche de nouveaux disinfectants pour les produits de 4ème gamme. Proc. Congress Produits de 4éme Gamme et de 5ème Gamme. Brussels: CERIA.

Mensah, P., Yeboah-Manu, D., Owusu-Darko, K., \& Ablordey, A. (2002). Street foods in Accra, Ghana: How safe are they? Bulletin of the World Health Organization, 80(7), 546-554.

MOFA-GIDA. (2011). National irrigation policy, strategies and regulatory measures. Accra, Ghana: Ministry of Food and Agriculture and the Ghana Irrigation Development Authority.

Obuobie, E., Keraita, B., Danso, G., Amoah, P., Cofie, O., Raschid-Sally, L., \& Drechsel, P. (2006). Irrigated urban vegetable production in Ghana: Characteristics, benefits and riskes. Accra, Ghana: IWMI, Resource Centre on Urban Agriculture and Food Security (RUAF), CGIAR Challenge Program on Water \& Food (CPWF). Available at http://www.cityfarmer. org/GhanaIrrigateVegis.html
Raschid-Sally, L., \& Jayakody, P. (2008). Drivers and characteristics of wastewater agriculture in developing countries: Results from a global assessment. IWMI Research Report 127. Colombo, Sri Lanka: IWMI.

Rheinländer, T., Olsen, M., Bakang, J. A., Takyi, H., Konradsen, F., \& Samuelsen, H. (2008). Keeping up appearances: Perceptions of street food safety in urban Kumasi, Ghana. Journal of Urban Health, 85(6), 952-964. http://dx.doi.org/10.1007/s11524-0089318-3

Rifkin, S. B., \& Pridmore, P. (2001). Partners in planning: Information, participation and empowerment. London: Macmillian Education Ltd.

Shuval, H. I., Adin, A., Fattal, B., Rawitz, E., \& Yekutiel, P. (1986). W astewater irrigation in developing countries: Health effects and technical solutions (Volume 1). World Bank Technical Paper No. 51. Washington, D.C.: World Bank.

Siegel, M., \& Doner-Lotenberg, L. (2007). Marketing public health: Strategies to promote social change (Second ed.). Boston: Jones \& Bartlett Publishers.

Stevik, T. K., Aa, K., Ausland, G., \& Hanssen, J. F. (2004). Retention and removal of pathogenic bacteria in wastewater percolating through porous media. Water Research, 38, 1355-1367.

United Nations Food and Agriculture Organization [FAO]. (1992). Wastewater treatment and use in agriculture. FAO Irrigation and Drainage paper 47. Rome: Author.

United Nations Food and Agriculture Organization [FAO]. (2002). Agricultural drainage water management in arid and semi-arid areas. FAO Irrigation and Drainage Paper 61. Rome: Author.

United Nations Food and Agriculture Organization [FAO]. (2007). The urban producer's resource book. Retrieved from http://www.fao.org/docrep/010/ a1177e/a1177e00.htm

World Health Organization [WHO]. (2006). Guidelines for the safe use of wastewater, excreta and grey water: $W$ astewater use in agriculture (Volume 2). Report of a WHO Scientific Group. WHO Technical Report Series 778. Geneva: Author.

WHO \& United Nations Children's Fund [UNICEF]. (2000). Global water supply and sanitation assessment 2000 report. Geneva and New York: Authors.

World Bank. (2006). Enhancing agricultural innovation: How to go beyond the strength of research systems. The International Bank for Reconstruction and Development. Washington, D.C.: Author. 